\title{
Ice nucleation activity in the widespread soil fungus Mortierella alpina
}

\author{
J. Fröhlich-Nowoisky ${ }^{1}$, T. C. J. Hill ${ }^{2}$, B. G. Pummer ${ }^{1}$, P. Yordanova ${ }^{1}$, G. D. Franc ${ }^{3, \dagger}$, and U. Pöschl ${ }^{1}$ \\ ${ }^{1}$ Max Planck Institute for Chemistry, Multiphase Chemistry Department, Mainz, Germany \\ ${ }^{2}$ Colorado State University, Department of Atmospheric Science, Fort Collins, USA \\ ${ }^{3}$ University of Wyoming, Plant Sciences Department, Laramie, USA \\ $\dagger$ Deceased \\ Correspondence to: J. Fröhlich-Nowoisky (j.frohlich@mpic.de)
}

Received: 8 July 2014 - Published in Biogeosciences Discuss.: 29 August 2014

Revised: 19 December 2014 - Accepted: 14 January 2015 - Published: 19 February 2015

\begin{abstract}
Biological residues in soil dust are a potentially strong source of atmospheric ice nuclei (IN). So far, however, the abundance, diversity, sources, seasonality, and role of biological - in particular, fungal - IN in soil dust have not been characterized. By analysis of the culturable fungi in topsoils, from a range of different land use and ecosystem types in southeast Wyoming, we found ice-nucleationactive (INA) fungi to be both widespread and abundant, particularly in soils with recent inputs of decomposable organic matter. Across all investigated soils, $8 \%$ of fungal isolates were INA. All INA isolates initiated freezing at -5 to $-6{ }^{\circ} \mathrm{C}$, and belonged to a single zygomycotic species, Mortierella alpina (Mortierellales, Mortierellomycotina). To our knowledge this is the first report of ice nucleation activity in a zygomycotic fungi because the few known INA fungi all belong to the phyla Ascomycota and Basidiomycota. M. alpina is known to be saprobic and widespread in soil, and Mortierella spores are present in air and rain. Sequencing of the ITS region and the gene for $\gamma$-linolenic elongase revealed four distinct clades, affiliated to different soil types. The IN produced by M. alpina seem to be proteinaceous, $<300 \mathrm{kDa}$ in size, and can be easily washed off the mycelium. Ice nucleating fungal mycelium will ramify topsoils and probably also release cell-free IN into it. If these IN survive decomposition or are adsorbed onto mineral surfaces, their contribution might accumulate over time, perhaps to be transported with soil dust and influencing its ice nucleating properties.
\end{abstract}

\section{Introduction}

Soil organic matter has long been proposed as a source of atmospheric ice nuclei (IN), and biological IN can dominate the fraction active at warmer temperatures (Schnell and Vali, 1972, 1976; Conen et al., 2011; O’Sullivan et al., 2014). When soils dry, small particles are liable to be aerosolized (Sing and Sing, 2010); soil dust emissions to the global atmosphere are estimated to be in the range of 500 to $5000 \mathrm{Tg} \mathrm{a}^{-1}$ (Goudie and Middleton, 2001). This makes large areas of the global landmass potentially strong sources of atmospheric biological IN, especially when the uplifting of dust by agricultural activities such as ploughing and harvesting is considered.

However, the sources and characteristics of biological IN produced and released by soils are poorly understood, and their contribution to the pool of the atmospheric IN remains unclear, even though their role in triggering glaciation and precipitation has recently been supported (Pratt et al., 2009; Creamean et al., 2013). Indeed, it has been suggested that most IN active at warmer than $-15^{\circ} \mathrm{C}$ in clouds could be biological particles (DeMott and Prenni, 2010).

Several diverse bioaerosol types, including bacteria, fungi, pollen, and lichen, have been identified as sources of biological IN, with some able to initiate the formation of ice at relatively high temperatures (Vali et al., 1976; Kieft, 1988; Pouleur et al., 1992; Diehl et al., 2001; Morris et al., 2004; Christner et al., 2008; Bowers et al., 2009; Georgakopoulos et al., 2009; Iannone et al., 2011). The best known are species of common plant-associated bacteria from the genera 
Pseudomonas, Pantoea, and Xanthomonas (all within the $\gamma$ Proteobacteria). The ice nucleation activity of these bacteria is due to a protein embedded in the outer cell membrane, for which the corresponding gene has been identified and fully sequenced (Warren, 1995). In contrast, for ice-nucleationactive (INA; i.e., inducing ice formation in the probed range of temperature and concentration) eukaryotes, much less is known about the nature of their IN. For example, for some known species of INA fungi (Pouleur et al., 1992; Richard et al., 1996) - several species of Fusarium - there are indications that their IN are also proteinaceous (Hasegawa et al., 1994; Tsumuki and Konno, 1994: Humphreys et al., 2001). Similarly, the sensitivity of lichen mycobiont IN (Kieft, 1988) to protein-degrading treatments and heating $>70^{\circ} \mathrm{C}$ suggests that a similar molecular class is responsible (Kieft and Ahmadjian, 1989; Kieft and Ruscetti, 1990). However, other classes of molecules have also been shown to be INA. For example, an analysis of more than a dozen species of pollen showed that the IN are soluble macromolecules located on the grains, and that they show non-proteinaceous characteristics (Pummer et al., 2012). Furthermore, studies of IN in fluids of succulent plants point at saccharide compounds as being the INA sites (Krog et al., 1979; Goldstein and Nobel, 1991, 1994).

So far, only a few ascomycotic and basidiomycotic fungal species have been reported as being INA (Jayaweera and Flanagan, 1982; Kieft, 1988; Pouleur et al., 1992; Richard et al., 1996; Haga et al., 2013; Morris et al., 2013), but this is likely to rise significantly when systematic surveys of ice nucleation activity by soil or phylloplane fungi are undertaken. In soil, the typical decomposer community, which accounts for half a percent to a few percent of the soil organic matter (Wardle, 1992; Zak et al., 1994; Fierer et al., 2009), is often dominated by fungi; estimates of the average proportions of fungi in the total microbial biomass range from $35-75 \%$ in arable/grassland soils, to $47-70 \%$ in forest soils, and to 64-76\% in litters (Joergensen and Wichern, 2008). Ice nuclei produced by soil fungi may occur as living and recently dead hyphae, spores, cell-free IN, and even as a constituent of the soil organic matter if the biomolecules are more enduring than the fungal tissue or are adsorbed onto soil organic matter or clay.

Currently, little is known of the sources, abundance, spectra of IN activities, seasonality, and, ultimately, the overall contribution of fungal IN to the large pools of biological IN in most soils. By extension, we know even less about their influence in the atmosphere. Thus, the objective of this study is a regional investigation of the identity and relative abundances of culturable INA fungi in topsoils, an essential base for improving our understanding of the effects of microorganisms on climate and the hydrological cycle.

\section{Material and methods}

\subsection{Sampling}

In March 2011, five soil samples were collected from the University of Wyoming's Agricultural Experimental Station (SAREC) near Lingle, Wyoming, USA. Three samples were obtained from plots cropped to different broadleaf crops in an irrigated field, a fourth from a plot under fallow in an irrigated and organically managed field, and a fifth from a section of unmanaged roadside pasture. In May 2011, soil was sampled from native grassland and from beneath a lodgepole pine forest near Centennial, Wyoming (Table 1a, b).

At each plot or site, three replicate soil samples were obtained. Each was obtained from a separate $10 \times 10 \mathrm{~m}$ area, and within each area three cores $(5 \mathrm{~cm}$ depth and $\approx 10 \mathrm{~cm}$ in diameter) were retrieved and mixed together on site. Samples were stored at $4{ }^{\circ} \mathrm{C}$ for less than a week before being thoroughly mixed immediately before soil dilution plating.

\subsection{Cultivation}

For cultivation of the soil fungi, dilution series were made using $0.45 \mu \mathrm{m}$ pore diameter filtered $0.01 \mathrm{MPO}_{4}$ buffer $(\mathrm{pH}$ 7.0) and $0.1 \%$ peptone (Difco Proteose Peptone No. 3; Becton, Dickinson and Company, USA). Two hundred and fifty microliters of dilutions $10^{-2}-10^{-6}$ were plated onto dextrose-peptone-yeast extract (DPY) solid medium (see below), and colonies were allowed to grow for 3-7 days at room temperature (RT, $22-24^{\circ} \mathrm{C}$ ) before being picked, using sterile pipette tips, into $100 \mu \mathrm{L}$ aliquots of $0.2 \mu \mathrm{m}$ pore diameter filtered DPY broth in sterile 96-well polypropylene PCR plates (VWR, USA), which were incubated at $16^{\circ} \mathrm{C}$ for 7-10 days. After the first aliquot was tested, as described below, fresh DPY broth was added and the cultures were tested again after 20-30 days of incubation. Out of 489 picked colony forming units (CFUs), 474 showed growth in the liquid medium and were thus tested for ice nucleation activity.

We originally intended to grow the isolates on malt extract agar. However, since the available product was found to contain some IN (active at $-12^{\circ} \mathrm{C}$ ), an approximate equivalent using IN-free ingredients (tested to $-18^{\circ} \mathrm{C}$ ) was constructed. This DPY broth/solid medium contained $10 \mathrm{~g} \mathrm{~L}^{-1}$ dextrose (VWR, USA), $3 \mathrm{~g} \mathrm{~L}^{-1}$ peptone (as detailed above), and $0.3 \mathrm{~g} \mathrm{~L}^{-1}$ yeast extract (Merck, USA) filtered through a $0.2 \mu \mathrm{m}$ pore diameter filter (PES disposable filter units, Life Science Products, USA). For the solid medium, $15 \mathrm{gL}^{-1}$ agarose (Certified Molecular Biology Agarose, Bio-Rad, USA) was added, since standard agar was also found to contain IN. Broth and solid medium were sterilized by autoclaving at $121^{\circ} \mathrm{C}$ for $20 \mathrm{~min}$, then the agar was dispensed into $150 \mathrm{~mm}$ petri dishes (Greiner, USA). 
Table 1a. Description of sampling sites.

\begin{tabular}{|c|c|c|c|c|c|c|c|c|}
\hline Site & $\begin{array}{l}\text { Sampling date } \\
\text { (2011) }\end{array}$ & Lat & Long & $\begin{array}{r}\text { Elevation } \\
(\mathrm{m})\end{array}$ & $\begin{array}{c}\text { Annual } \\
\text { precipitation (mm) }\end{array}$ & $\begin{array}{r}\text { Annual avg } \\
T\left({ }^{\circ} \mathrm{C}\right)\end{array}$ & $\begin{array}{r}\text { Days with } \\
\text { air } T<0^{\circ} \mathrm{C}\end{array}$ & Vegetation \\
\hline \multicolumn{9}{|c|}{ Crop soils } \\
\hline Alfalfa $^{a}$ & $2 \mathrm{Mar}$ & 42.12266 & -104.38585 & 1270 & 336 & 9.3 & 181 & $\begin{array}{l}\text { Dead material on surface from } \\
\text { previous year's sowing of al- } \\
\text { falfa, orchard grass, and meadow } \\
\text { brome. }\end{array}$ \\
\hline Bean $^{\mathrm{a}}$ & $2 \mathrm{Mar}$ & 42.13167 & -104.39413 & 1270 & 336 & 9.3 & 181 & $\begin{array}{l}\text { Bare at sampling. Previous year } \\
\text { was a mixed crop of dry beans. }\end{array}$ \\
\hline Potato $^{a}$ & $2 \mathrm{Mar}$ & 42.13167 & -104.39516 & 1270 & 336 & 9.3 & 181 & $\begin{array}{l}\text { Bare at sampling. Previous year } \\
\text { was potato. }\end{array}$ \\
\hline Sugar beet ${ }^{\mathrm{a}}$ & $2 \mathrm{Mar}$ & 42.12878 & -104.39516 & 1270 & 336 & 9.3 & 181 & $\begin{array}{l}\text { Bare at sampling. Previous year } \\
\text { was Roundup Ready sugar beet. }\end{array}$ \\
\hline \multicolumn{9}{|c|}{ Native and uncultivated soils } \\
\hline Forest $^{\mathrm{b}}$ & 24 May & 41.32436 & -106.16007 & 2610 & 385 & 4.6 & 214 & $\begin{array}{l}\text { Lodgepole pine, with understory } \\
\text { of elk sedge, low sedge, creeping } \\
\text { juniper, Oregon grape, kinnikin- } \\
\text { nick, woods rose, and heartleaf } \\
\text { arnica. }\end{array}$ \\
\hline Grassland $^{\mathrm{b}}$ & 24 May & 41.2881 & -106.11124 & 2420 & 385 & 4.6 & 214 & $\begin{array}{l}\text { Bluebunch wheatgrass, Idaho } \\
\text { fescue, western wheatgrass, and } \\
\text { threetip sagebrush. }\end{array}$ \\
\hline Pasture $^{\mathrm{a}}$ & $2 \mathrm{Mar}$ & 42.13243 & -104.39428 & 1270 & 336 & 9.3 & 181 & $\begin{array}{l}\text { Smooth brome and downy } \\
\text { brome. }\end{array}$ \\
\hline
\end{tabular}

${ }^{\mathrm{a}}$ Lingle ${ }^{\mathrm{b}}$ Centennial.

Table 1b. Characterization of soil samples.

\begin{tabular}{|c|c|c|c|c|}
\hline Site & Soil type & $\% \mathrm{SOM}^{\mathrm{c}}$ & $\% \mathrm{~N}$ & $\mathrm{pH}$ \\
\hline \multicolumn{5}{|c|}{ Crop soils } \\
\hline Alfalfa & $\begin{array}{l}\text { Haverson \& McCook light brownish-gray } \\
\text { floodplain loams. }{ }^{\text {a }}\end{array}$ & 0.95 & 0.076 & 8.1 \\
\hline Bean & $\begin{array}{l}\text { Haverson \& McCook light brownish-gray } \\
\text { floodplain loams. }{ }^{\text {a }}\end{array}$ & - & - & - \\
\hline Potato & $\begin{array}{l}\text { Haverson \& McCook light brownish-gray } \\
\text { floodplain loams. }\end{array}$ & - & - & - \\
\hline Sugar beet & $\begin{array}{l}\text { Haverson \& McCook light brownish-gray } \\
\text { floodplain loams. }{ }^{\text {a }}\end{array}$ & 1.3 & 0.11 & 8.15 \\
\hline \multicolumn{5}{|c|}{ Native and uncultivated soils } \\
\hline Grassland & $\begin{array}{l}\text { Greyback very cobbly sandy loam; out- } \\
\text { wash from alluvial fan. Surface layer grayish } \\
\text { brown to brown very cobbly sandy loam. }{ }^{\text {b }}\end{array}$ & 3.7 & 0.27 & 6.45 \\
\hline Forest & $\begin{array}{l}\text { Ansile-Granile gravelly sandy loam. } 5 \mathrm{~cm} \\
\text { layer of needles and bark residue. }\end{array}$ & 100 & 2.05 & 5.9 \\
\hline Pasture & $\begin{array}{l}\text { Haverson \& McCook light brownish-gray } \\
\text { floodplain loams. }{ }^{\text {a }}\end{array}$ & 4.7 & 0.465 & 7.85 \\
\hline
\end{tabular}

a Soil survey of Goshen County, south part, Wyoming, 1971. United States Department of Agriculture, Soil Conservation Service, 102 pp. ${ }^{b}$ Soil survey of Albany County Area, Wyoming, 1998. United States Department of Agriculture, Natural Resources

Conservation Service, U.S Government Printing Office, 540 pp. ${ }^{\mathrm{c}}$ Soil organic matter (SOM) contents obtained by multiplying percentage carbon by 1.724

\subsection{Initial screening for ice nucleation activity}

An aliquot of each culture containing visible mycelia was tested for its ice nucleation activity in a temperature range from -2 to $-12{ }^{\circ} \mathrm{C}$. Aliquots of $50 \mu \mathrm{L}$ were transferred to wells of a fresh, sterile, 96-well PCR tray which was cooled in a thermal cycler (PTC-200, MJ Research, USA). The cy- cler was programmed to descend in 0.5 or $1^{\circ} \mathrm{C}$ decrements from -2 to $-9{ }^{\circ} \mathrm{C}$ (the limit of the machine). Temperature variation across the cooling block was $\pm 0.2^{\circ} \mathrm{C}$ of the real temperature measured using a thermistor (VPT-0300, BioRad, USA). After a 5 min dwell time at each temperature, the number of frozen wells was counted and the temperature lowered to the next level. Once cooled to $-9{ }^{\circ} \mathrm{C}$, the tray was transferred to a 96-well aluminum incubation block (VWR, USA) which had been precooled to $\approx-12{ }^{\circ} \mathrm{C}$ inside a foam box in a freezer. The thermistor was inserted into a side well and after 10 min the block temperature and number of frozen wells was recorded. Aliquots of uninoculated DPY broth were used as negative controls. Ice-nucleationactive Fusarium acuminatum cultures (provided courtesy of Linda Hanson, Michigan State University) were used as positive controls ( $\approx 10^{9} \mathrm{IN} \mathrm{g}^{-1}$ mycelium). Ice-nucleation-active isolates were then subcultured on DPY agar, incubated at RT for 3-7 days, and tested again (aerial mycelium picked and suspended in $50 \mu \mathrm{L}$ fresh DPY broth) to confirm activity. To test for possible contaminants, microscopic investigations as well as qPCR on the bacterial ina gene following the protocol by Hill et al. (2014) were performed. Cultures which seemed to be mixed were subcultured by plating small pieces from the diffuse leading edge of growth to recover single isolates. Only pure cultures were used for further freezing tests and identification. 


\subsection{Identification and phylogenetic analysis}

For identification and phylogenetic analyses, hyphae and spores were first picked using sterile pipette tips (Eppendorf, Germany) into $20 \mu \mathrm{L}$ water and lysed at $95^{\circ} \mathrm{C}$ for $10 \mathrm{~min}$. This lysate was used as a PCR template. To amplify fungal DNA for sequencing, two PCRs, one of the internal transcribed spacer (ITS) and a second of a gene for $\gamma$-linolenic elongase (GLELO), were performed. Each $25 \mu \mathrm{L}$ reaction mixture contained the template DNA $(1 \mu \mathrm{L}), 1 \times$ PCR buffer (Sigma-Aldrich, Germany), $0.2 \mathrm{mM}$ each dNTP (Roth, Germany), $0.33 \mu \mathrm{M}$ of each primer (Sigma-Aldrich, Germany), and 1.25 units of JumpStart ${ }^{\mathrm{TM}}$ REDTaq DNA polymerase (Sigma-Aldrich, Germany). A negative control was included in all PCR runs.

PCR reactions were performed with the primer pairs GLELOfor/GLELOrev (Takeno et al., 2005) and ITS4/ITS5 (White et al., 1990). The thermal profile (DNA Engine, BioRad Laboratories, Germany) was as follows: initial denaturing at $94{ }^{\circ} \mathrm{C}$ for $3 \mathrm{~min} ; 35$ cycles with denaturing at $94^{\circ} \mathrm{C}$ for $30 \mathrm{~s}$, annealing at $52.5^{\circ} \mathrm{C}$ for $60 \mathrm{~s}$ (GLELO) or $54^{\circ} \mathrm{C}$ for $30 \mathrm{~s}$ (ITS), elongation at $72{ }^{\circ} \mathrm{C}$ for $90 \mathrm{~s}$ (GLELO) or $45 \mathrm{~s}$ (ITS); and a final extension step at $72{ }^{\circ} \mathrm{C}$ for $5 \mathrm{~min}$.

Amplification products for sequencing were cloned using the TOPO TA Cloning ${ }^{\circledR}$ Kit (Invitrogen, Germany) following the supplier's instructions. Colonies containing inserts were identified by means of blue-white selection and lysed in $20 \mu \mathrm{L} \mathrm{H} \mathrm{H}_{2} \mathrm{O}$ for $10 \mathrm{~min}$ at $95^{\circ} \mathrm{C}$. The inserts of $6-12$ colonies of each cloning reaction were amplified using $1.5 \mu \mathrm{L}$ cell lysate in a $25 \mu \mathrm{L}$ reaction. The PCR reaction mixture contained $1 \times$ JumpStartREDTaq Ready Mix (Sigma-Aldrich, Germany) and $0.25 \mu \mathrm{M}$ of each primer (Sigma-Aldrich, Germany). PCR reactions were performed with the primer pair M13F-40 and M13R, and the thermal profile was as follows: initial denaturing at $94^{\circ} \mathrm{C}$ for $5 \mathrm{~min} ; 40$ cycles at $94^{\circ} \mathrm{C}$ for $30 \mathrm{~s}$, annealing at $55^{\circ} \mathrm{C}$ for $1 \mathrm{~min}$, elongation at $72^{\circ} \mathrm{C}$ for $1 \mathrm{~min}$; and a final extension step at $72^{\circ} \mathrm{C}$ for $15 \mathrm{~min}$. For sequencing, up to 10 colony PCR products per isolate and gene were chosen.

DNA sequences were determined with ABI Prism 377, 3100, and 3730 sequencers (Applied Biosystems, Germany) using BigDye Terminator v3.1 chemistry at the Max Planck Genome Centre of the Max Planck Institute for Plant Breeding Research, Cologne, Germany. The quality of all sequences was manually checked. For comparison with known sequences, databank queries using the Basic Local Alignment Search Tool (BLAST) were performed via the website of the National Center for Biotechnology Information (NCBI, http://www.ncbi.nlm.nih.gov/). Alignments were done using ClustalW within BioEdit (http://www.mbio. ncsu.edu/bioedit/bioedit.html) and manually checked. Phylogenetic trees were constructed using MEGA version 5 (Tamura et al., 2011). MEGA's model selection facility was used to choose the best models by employing the maximum likelihood method and optimizing a neighbor-joining (NJ) tree. DNA- and amino acid-derived trees were calculated using NJ with a 2000-replicate bootstrap analysis (Felsenstein, 1985).

\subsection{Freezing spectra (number of IN)}

After initial selection and identification, the fungi were subcultured on PDA (potato dextrose agar, VWR, Germany) plates, and further freezing experiments were performed to characterize their ice nucleation activity. To perform tests below $-9^{\circ} \mathrm{C}$, another ice spectrometer for droplet arrays using 96-well PCR trays was constructed. Holes were drilled through the base of a 96-well aluminum block (VWR, Germany), which was then connected to a Julabo Presto A30 cooling bath operating with Thermal HL40 (Julabo, Germany) as cooling liquid. For accurate control and regulation of the block temperature, an additional PT100 temperature sensor was integrated within the aluminum block. The block, which was initially stabilized at $-4^{\circ} \mathrm{C}$, was then cooled in 0.5 to $2{ }^{\circ} \mathrm{C}$ steps to $-15^{\circ} \mathrm{C}$. Each transition took $12 \mathrm{~min}$ in order to allow time for the system to equilibrate and dwell at the new temperature for at least $5 \mathrm{~min}$. The number of frozen wells was counted.

For the determination of the IN per gram of mycelium, the entire mass of mycelium (containing spores) of a fungal culture was harvested by scraping it off the PDA surface and transferred it into a sterile $15 \mathrm{~mL}$ Falcon tube (SPL Lifesciences, Korea) which was weighed before and after harvesting. Depending on the individual isolates, between 0.1 and $1.3 \mathrm{~g}$ of mycelium could be harvested. Ten milliliters of $0.1 \mu \mathrm{m}$ pore diameter sterile, filtered (Acrodisc, PES, Pall, Germany), deionized water was added and the suspension shaken for $1 \mathrm{~min}$ on a vortex mixer. The solution was then filtered through a $5 \mu \mathrm{m}$ pore diameter filter (Acrodisc, PES, Pall, Germany) and diluted up to $10^{-8}$ with $0.1 \mu \mathrm{m}$ pore diameter filtered deionized water. From several of the dilutions, 24-88 (mostly 32) aliquots of $50 \mu \mathrm{L}$ were then tested for freezing as described above. Aliquots of $0.1 \mu \mathrm{m}$ pore diameter filtered deionized water were used as negative controls. The absence of IN on the PDA plates was confirmed as follows: a loop was scraped over the agar surface, as during mycelium harvest, and then dipped into $0.1 \mu \mathrm{m}$ pore diameter filtered deionized water, which was tested. The concentration of IN per gram of mycelium was calculated using a variant of the formula of Vali (Eq. 1, Vali, 1971):

$n_{\mathrm{m}}\left[g^{-1}\right]=-\ln \left(1-f_{\text {ice }}\right) \cdot \frac{V_{\text {wash }}}{V_{\text {drop }}} \cdot \frac{F_{\text {dil }}}{m_{\mathrm{myc}}}$,

where $n_{\mathrm{m}}$ is the number of IN per gram of mycelium, $f_{\text {ice }}$ the fraction of frozen droplets, $V_{\text {wash }}$ the volume of water added for washing $\left(10 \mathrm{~mL}\right.$ in this study), $V_{\text {drop }}$ the droplet volume in the freezing assay $(0.05 \mathrm{~mL}$ in this study $), F_{\text {dil }}$ the dilution factor of the suspension, and $m_{\mathrm{myc}}$ the mass of the mycelium. Binomial confidence intervals ( $\mathrm{CI}_{95} \%$ ) were derived by using 
Eq. (2) as recommended by Agresti and Coull (1998):

$$
\mathrm{Cl}_{95 \%}=\left(f_{\text {ice }}+\frac{1.96^{2}}{2 n} \pm 1.96 \sqrt{\left[f_{\text {ice }}\left(1-f_{\text {ice }}\right)+1.96^{2} / 4 n\right] / n}\right)
$$

$/\left(1+1.96^{2} / n\right)$,

where $n$ is the total number of droplets.

\subsection{Size and mass determination of the IN}

The $5 \mu \mathrm{m}$ filtrate was further filtered through $0.1 \mu \mathrm{m}$ pore size filters (Acrodisc, PES, Pall, Germany) and Vivaspin ${ }^{\circledR}$ filter tubes (Sartorius, Germany) of different mass exclusion limits $(100,300 \mathrm{kDa})$. These filtrates were then tested for freezing activity as described above.

\subsection{Enzymatic, chemical, and heat treatments}

To further characterize the IN, the effects of proteinand lipid-degrading enzymes, protein- and carbohydratedegrading chemicals, and heat were investigated. Aliquots of the $0.1 \mu \mathrm{m}$ filtrates were treated as follows: (A) $1 \mathrm{~h}$ with $50 \mathrm{mg} \mathrm{mL}^{-1}$ of the enzymes: (i) papain (AppliChem, Germany) at $60^{\circ} \mathrm{C}$, (ii) pepsin (Sigma-Aldrich, Germany) at $37^{\circ} \mathrm{C}, \mathrm{pH} 1.5$, or (iii) lipase (AppliChem, Germany) at $37^{\circ} \mathrm{C}$; (B) $1-2 \mathrm{~h}$ at room temperature with (i) $6 \mathrm{M}$ guanidinium chloride (Promega, Germany) or (ii) $0.3 \mathrm{M}$ boric acid (National Diagnostics, USA); and (C) $1 \mathrm{~h}$ at (i) $60^{\circ} \mathrm{C}$ or (ii) $98^{\circ} \mathrm{C}$. Controls of enzyme or chemical solutions of the same concentration were included as reference measurements. The ice nucleation activity of the treated aliquots was tested after appropriate dilution as described above.

\subsection{Nucleotide sequence accession numbers}

The sequences from the isolates of the present study have been deposited in GenBank under accession numbers KJ469804-KJ469842 for internal transcribed spacer (ITS) sequences and KJ469843-KJ469875 for GLELO $(\gamma$ linolenic elongase) sequences.

\section{Results}

Soil samples were collected in spring 2011 at four cropped sites, one pasture, and from two areas of native vegetation in southeast Wyoming, USA (see Table 1a, b for site and soil details). Soil dilution series were prepared and all 474 fungal CFUs obtained were tested for ice nucleation activity to $-15^{\circ} \mathrm{C}$. As shown in Tables 2 and 3, $8 \%$ (39) of all CFUs from these seven soils showed freezing activity between -5 and $-6^{\circ} \mathrm{C}$. The proportion of INA fungi varied for different soils, from $0 \%$ in the bean plot to $25 \%$ in an adjacent sugar beet plot (crops are the previous season's plantings, since plots were still bare at the time of sampling).
Table 2. Numbers and concentration of cultivable fungi and ice nucleating M. alpina in different soil types.

\begin{tabular}{|c|c|c|c|c|c|}
\hline & $\begin{array}{l}\text { Total } \\
\text { CFU }\end{array}$ & $\begin{array}{c}\text { INA } M \text {. alpina } \\
\text { CFU }\end{array}$ & & $\begin{array}{c}\text { Fungi } \\
\left(\mathrm{CFU} \mathrm{g}^{-1}\right)\end{array}$ & $\begin{array}{l}\text { INA } M \text {. alpina } \\
\quad\left(\mathrm{CFU} \mathrm{g}^{-1}\right)\end{array}$ \\
\hline Number & 474 & 39 & Mean & $6.0 \times 10^{4}$ & $2.9 \times 10^{3}$ \\
\hline \multicolumn{6}{|c|}{ Crop soils } \\
\hline Alfalfa & 65 & 3 & & $5.3 \times 10^{4}$ & $6.0 \times 10^{2}$ \\
\hline Bean & 21 & - & & $8.4 \times 10^{4}$ & - \\
\hline Potato & 12 & 2 & & $4.8 \times 10^{4}$ & $4.0 \times 10^{3}$ \\
\hline Sugar beet & 88 & 22 & & $6.4 \times 10^{4}$ & $8.0 \times 10^{3}$ \\
\hline \multicolumn{6}{|c|}{ Native and uncultivated soils } \\
\hline Forest & 36 & 6 & & $4.3 \times 10^{4}$ & $4.8 \times 10^{3}$ \\
\hline Grassland & 52 & 1 & & $3.3 \times 10^{4}$ & $2.0 \times 10^{2}$ \\
\hline Pasture & 200 & 5 & & $9.7 \times 10^{4}$ & $2.8 \times 10^{3}$ \\
\hline
\end{tabular}

All 39 INA isolates were identified as Mortierella alpina (Mortierellales; Mucoromycotina/Mortierellomycotina; Hibbett et al., 2007; Hoffmann et al., 2011) based on sequencing of both the ITS regions and the GLELO ( $\gamma$-linolenic elongase) gene (Table 3 ). The identity of the sequences with the best matches in the GenBank database was $99-100 \%$ (Table 3), although they showed a wider range of 95-100\% similarity when compared to each other, a reflection of the diversity within the group. Indeed, the identity level between the ITS regions of different $M$. alpina isolates ranges from 94 to $100 \%$ (Ho and Chen, 2008), almost twice the value of $3.24 \%$ suggested for intraspecific variability within the zygomycotic fungi by Nilsson and Kristiansson (2008). The phylogeny of Mortierellales is poorly understood and a new classification based on modern phylogenetic methods has been recommended (Petkovits et al., 2011).

For a better characterization of the M. alpina isolates, a NJ tree was constructed using a $515 \mathrm{bp}$ sequence of the partial ITS1-5.8S-partial ITS2 region of all INA isolates. Included for comparison were the best match sequences obtained from a BLAST search (Table 3), as well as sequences from M. humilis (AJ878778.1), M. gamsii (AJ878508.1), and M. macrocystis (AJ878781.1), which were used as out-groups (Kwaśna et al., 2006; Ho and Chen, 2008). As shown in Fig. 1, four clades of M. alpina were formed, each supported with high bootstrap values. These were classified as (A) predominantly uncultivated, (B) forest, (C) predominantly standard agricultural, and (D) high organic matter input agricultural. The isolates from the forest site were restricted to clade $\mathrm{B}$; the single native grassland isolate was placed in clade A; pasture and alfalfa isolates were mostly restricted to clade $\mathrm{C}$; and isolates from the harvested and ploughed sugar beet field, which contained many broken and decaying pieces of sugar beet root, accounted for $\approx 90 \%$ of group $\mathrm{D}$, as well as being common in clade $\mathrm{C}$.

In order to further characterize the populations, the GLELO gene was used; GLELO is responsible for the conversion of $\gamma$-linolenic acid to dihomo- $\gamma$-linolenic acid 
Table 3. Characteristics of $M$. alpina isolates. Site, ID number, phylogenetic clade, highest observed initial freezing temperature ( $\left.T_{\mathrm{i}}\right)$, and closest GenBank matches and similarity for ITS and GLELO; n.s. stands for no sequence.

\begin{tabular}{|c|c|c|c|c|c|c|c|}
\hline \multirow[b]{2}{*}{ Site } & \multirow[b]{2}{*}{ ID no. } & \multirow[b]{2}{*}{ Clade } & \multirow[b]{2}{*}{$\begin{array}{r}T_{\text {initial }} \\
\left({ }^{\circ} \mathrm{C}\right)\end{array}$} & \multicolumn{2}{|l|}{ ITS } & \multicolumn{2}{|l|}{ GLELO } \\
\hline & & & & $\begin{array}{l}\text { Closest isolates } \\
\text { (accession no.) }\end{array}$ & $\begin{array}{r}\text { Similarity } \\
(\%)\end{array}$ & $\begin{array}{l}\text { Closest isolates } \\
\text { (accession no.) }\end{array}$ & $\begin{array}{r}\text { Similarity } \\
(\%)\end{array}$ \\
\hline \multicolumn{8}{|c|}{ Crop soils } \\
\hline \multirow[t]{3}{*}{ Alfalfa } & 3 & D & -5 & $\begin{array}{r}\text { M. alpina xsd08339 } \\
\text { (EU918703) }\end{array}$ & 99.4 & $\begin{array}{r}\text { M. alpina ATCC } 32221 \\
\text { (AF206662) }\end{array}$ & 96.6 \\
\hline & 14 & $\mathrm{C}$ & -5.5 & $\begin{array}{r}\text { M. alpina CBS } 528.72 \\
(\mathrm{AJ} 271629)\end{array}$ & 99.6 & $\begin{array}{r}\text { M. alpina ATCC } 32221 \\
\text { (AF206662) }\end{array}$ & 97.8 \\
\hline & 34 & $\mathrm{C}$ & -6 & $\begin{array}{r}\text { M. alpina CBS 528.72 } \\
(\mathrm{AJ} 271629)\end{array}$ & 99.4 & $\begin{array}{r}\text { M. alpina ATCC } 32221 \\
\text { (AF206662) }\end{array}$ & 97.6 \\
\hline \multirow[t]{2}{*}{ Potato } & 12 & D & -5.5 & $\begin{array}{r}\text { M. alpina xsd08339 } \\
\text { (EU918703) }\end{array}$ & 99.3 & $\begin{array}{r}\text { M. alpina ATCC } 32221 \\
\text { (AF206662) }\end{array}$ & 96.6 \\
\hline & 13 & A & -5.5 & $\begin{array}{r}\text { M. alpina ATT234 } \\
\text { (HQ607903) }\end{array}$ & 99.7 & $\begin{array}{r}\text { M. alpina } \\
\text { (EU639657) }\end{array}$ & 99.3 \\
\hline \multirow[t]{18}{*}{ Sugar beet } & 5 & D & -5 & $\begin{array}{r}\text { M. alpina xsd08339 } \\
\text { (EU918703) }\end{array}$ & 99.1 & $\begin{array}{r}\text { M. alpina ATCC } 32221 \\
\text { (AF206662) }\end{array}$ & 96.6 \\
\hline & 6 & $\mathrm{D}$ & -5.5 & $\begin{array}{r}\text { M. alpina xsd08339 } \\
\text { (EU918703) }\end{array}$ & 99.3 & $\begin{array}{r}\text { M. alpina ATCC } 32221 \\
\text { (AF206662) }\end{array}$ & 96.6 \\
\hline & 7 & D & -5.5 & $\begin{array}{r}\text { M. alpina xsd08339 } \\
\text { (EU918703) }\end{array}$ & 99.3 & $\begin{array}{r}\text { M. alpina ATCC } 32221 \\
\text { (AF206662) }\end{array}$ & 96.4 \\
\hline & 8 & D & -5 & $\begin{array}{r}\text { M. alpina xsd08339 } \\
\text { (EU918703) }\end{array}$ & 99.1 & $\begin{array}{r}\text { M. alpina ATCC } 32221 \\
\text { (AF206662) }\end{array}$ & 96.6 \\
\hline & 9 & D & -5.5 & $\begin{array}{r}\text { M. alpina xsd08339 } \\
\text { (EU918703) }\end{array}$ & 99.0 & n.s & - \\
\hline & 10 & $\mathrm{D}$ & -5 & $\begin{array}{r}\text { M. alpina xsd08339 } \\
\text { (EU918703) }\end{array}$ & 99.1 & $\begin{array}{r}\text { M. alpina ATCC } 32221 \\
\text { (AF206662) }\end{array}$ & 96.6 \\
\hline & 11 & D & -5.5 & $\begin{array}{r}\text { M. alpina xsd08339 } \\
\text { (EU918703) }\end{array}$ & 99.1 & $\begin{array}{r}\text { M. alpina ATCC } 32221 \\
\text { (AF206662) }\end{array}$ & 96.2 \\
\hline & 15 & $\mathrm{D}$ & -5.5 & $\begin{array}{r}\text { M. alpina xsd08339 } \\
\text { (EU918703) }\end{array}$ & 99.0 & $\begin{array}{r}\text { M. alpina ATCC } 32221 \\
\text { (AF206662) }\end{array}$ & 95.3 \\
\hline & 16 & $\mathrm{C}$ & -5.5 & $\begin{array}{r}\text { M. alpina CBS 528.72 } \\
(\mathrm{AJ} 271629)\end{array}$ & 99.3 & $\begin{array}{r}\text { M. alpina ATCC } 32221 \\
\text { (AF206662) }\end{array}$ & 97.5 \\
\hline & 17 & $\mathrm{C}$ & -5.5 & $\begin{array}{r}\text { M. alpina CBS } 528.72 \\
(\mathrm{AJ} 271629)\end{array}$ & 99.4 & $\begin{array}{r}\text { M. alpina ATCC } 32221 \\
\text { (AF206662) }\end{array}$ & 97.8 \\
\hline & 18 & D & -5.5 & $\begin{array}{r}\text { M. alpina xsd08339 } \\
\text { (EU918703) }\end{array}$ & 99.1 & n.s & - \\
\hline & 19 & $\mathrm{D}$ & -5 & $\begin{array}{r}\text { M. alpina xsd08339 } \\
\text { (EU918703) }\end{array}$ & 99.0 & $\begin{array}{r}\text { M. alpina ATCC } 32221 \\
\text { (AF206662) }\end{array}$ & 96.6 \\
\hline & 20 & D & -5 & $\begin{array}{r}\text { M. alpina xsd08339 } \\
\text { (EU918703) }\end{array}$ & 99.0 & $\begin{array}{r}\text { M. alpina ATCC } 32221 \\
\text { (AF206662) }\end{array}$ & 96.2 \\
\hline & 21 & D & -5.5 & $\begin{array}{r}\text { M. alpina xsd08339 } \\
\text { (EU918703) }\end{array}$ & 99.3 & n.s & - \\
\hline & 22 & $\mathrm{C}$ & -5.5 & $\begin{array}{r}\text { M. alpina CBS 528.72 } \\
\text { (AJ271629) }\end{array}$ & 99.6 & $\begin{array}{r}\text { M. alpina ATCC } 32221 \\
\text { (AF206662) }\end{array}$ & 97.8 \\
\hline & 23 & D & -5.5 & $\begin{array}{r}\text { M. alpina xsd08339 } \\
\text { (EU918703) }\end{array}$ & 99.1 & $\begin{array}{r}\text { M. alpina ATCC } 32221 \\
\text { (AF206662) }\end{array}$ & 96.6 \\
\hline & 24 & $\mathrm{C}$ & -5.5 & $\begin{array}{r}\text { M. alpina CBS } 528.72 \\
(\mathrm{AJ} 271629)\end{array}$ & 99.6 & $\begin{array}{r}\text { M. alpina ATCC } 32221 \\
\text { (AF206662) }\end{array}$ & 97.1 \\
\hline & 25 & $\mathrm{D}$ & -5.5 & $\begin{array}{r}\text { M. alpina xsd08339 } \\
\text { (EU918703) }\end{array}$ & 99.3 & $\begin{array}{r}\text { M. alpina ATCC } 32221 \\
\text { (AF206662) }\end{array}$ & 96.6 \\
\hline
\end{tabular}


Table 3. Continued.

\begin{tabular}{|c|c|c|c|c|c|c|c|}
\hline \multicolumn{6}{|c|}{ ITS } & \multicolumn{2}{|l|}{ GLELO } \\
\hline Site & ID no. & Clade & $\begin{array}{r}T_{\text {initial }} \\
\left({ }^{\circ} \mathrm{C}\right)\end{array}$ & $\begin{array}{r}\text { Closest isolates } \\
\text { (accession no.) }\end{array}$ & $\begin{array}{r}\text { Similarity } \\
(\%)\end{array}$ & $\begin{array}{l}\text { Closest isolates } \\
\text { (accession no.) }\end{array}$ & $\begin{array}{r}\text { Similarity } \\
(\%)\end{array}$ \\
\hline \multicolumn{8}{|c|}{ Crop soils } \\
\hline & 26 & $\mathrm{C}$ & -6 & $\begin{array}{r}\text { M. alpina CBS } 528.72 \\
(\mathrm{AJ} 271629)\end{array}$ & 99.6 & $\begin{array}{r}\text { M. alpina ATCC } 32221 \\
\text { (AF206662) }\end{array}$ & 97.8 \\
\hline & 27 & $\mathrm{D}$ & -5.5 & $\begin{array}{r}\text { M. alpina xsd08339 } \\
\text { (EU918703) }\end{array}$ & 99.3 & $\begin{array}{r}\text { M. alpina ATCC } 32221 \\
\text { (AF206662) }\end{array}$ & 96.6 \\
\hline & 28 & $\mathrm{D}$ & -5.5 & $\begin{array}{r}\text { M. alpina xsd08339 } \\
\text { (EU918703) }\end{array}$ & 99.1 & $\mathrm{n} . \mathrm{s}$ & - \\
\hline & 42 & $\mathrm{C}$ & -5.5 & $\begin{array}{r}\text { M. alpina CBS 528.72 } \\
(\mathrm{AJ} 271629)\end{array}$ & 99.0 & $\begin{array}{r}\text { M. alpina ATCC } 32221 \\
\text { (AF206662) }\end{array}$ & 97.8 \\
\hline \multicolumn{8}{|c|}{ Native and uncultivated soils } \\
\hline \multirow[t]{6}{*}{ Forest } & 35 & B & -5.5 & $\begin{array}{r}\text { Unc. Mortierella clone } 1.12 \\
\text { (FN565294) }\end{array}$ & 98.9 & $\begin{array}{r}\text { M. alpina CBS } 608.70 \\
\text { (GU593327) }\end{array}$ & 93.3 \\
\hline & 36 & B & -5.5 & $\begin{array}{r}\text { Unc. Mortierella clone } 1.12 \\
\text { (FN565294) }\end{array}$ & 99.0 & n.s & - \\
\hline & 37 & B & -6 & $\begin{array}{r}\text { Unc. Mortierella clone } 1.12 \\
\text { (FN565294) }\end{array}$ & 98.9 & $\begin{array}{r}\text { M. alpina CBS } 608.70 \\
\text { (GU593327) }\end{array}$ & 93.3 \\
\hline & 38 & B & -6 & $\begin{array}{r}\text { Unc. Mortierella clone } 1.12 \\
\text { (FN565294) }\end{array}$ & 98.7 & $\begin{array}{r}\text { M. alpina CBS } 608.70 \\
\text { (GU593327) }\end{array}$ & 93.3 \\
\hline & 39 & B & -6 & $\begin{array}{r}\text { Unc. Mortierella clone 1.12 } \\
\text { (FN565294) }\end{array}$ & 98.9 & $\begin{array}{r}\text { M. alpina CBS } 608.70 \\
\text { (GU593327) }\end{array}$ & 93.3 \\
\hline & 40 & B & -5.5 & $\begin{array}{r}\text { Unc. Mortierella clone } 1.12 \\
\text { (FN565294) }\end{array}$ & 98.9 & n.s & - \\
\hline Grassland & 41 & A & -5 & $\begin{array}{r}\text { M. alpina ATT234 } \\
\text { (HQ607903) }\end{array}$ & 99.9 & $\begin{array}{r}\text { M. alpina } \\
\text { (EU639657) }\end{array}$ & 100 \\
\hline \multirow[t]{5}{*}{ Pasture } & 1 & A & -5 & $\begin{array}{r}\text { M. alpina ATT234 } \\
\text { (HQ607903) }\end{array}$ & 99.7 & $\begin{array}{r}\text { M. alpina } \\
\text { (EU639657) }\end{array}$ & 99.3 \\
\hline & 2 & $\mathrm{C}$ & -5.5 & $\begin{array}{r}\text { M. alpina CBS } 528.72 \\
(\mathrm{AJ} 271629)\end{array}$ & 99.6 & $\begin{array}{r}\text { M. alpina ATCC } 32221 \\
\text { (AF206662) }\end{array}$ & 97.8 \\
\hline & 31 & $\mathrm{C}$ & -5.5 & $\begin{array}{r}\text { M. alpina CBS } 528.72 \\
(\mathrm{AJ} 271629)\end{array}$ & 99.0 & $\begin{array}{r}\text { M. alpina ATCC } 32221 \\
\text { (AF206662) }\end{array}$ & 97.8 \\
\hline & 32 & $\mathrm{C}$ & -5.5 & $\begin{array}{r}\text { M. alpina CBS 528.72 } \\
(\mathrm{AJ} 271629)\end{array}$ & 99.6 & $\begin{array}{r}\text { M. alpina ATCC } 32221 \\
\text { (AF206662) }\end{array}$ & 97.5 \\
\hline & 33 & $\mathrm{C}$ & -5.5 & $\begin{array}{r}\text { M. alpina CBS 528.72 } \\
(\mathrm{AJ} 271629)\end{array}$ & 99.1 & $\begin{array}{r}\text { M. alpina ATCC } 32221 \\
\text { (AF206662) }\end{array}$ & 97.5 \\
\hline
\end{tabular}

(Takeno et al., 2005). GLELO DNA was successfully amplified from all four groups. A NJ tree was constructed by using a 447 bp sequence of the GLELO gene from 33 INA isolates and the closest matches obtained from BLAST (Fig. S1, Table 3 ). The tree again contained four clades with identical placement of the isolates in the clades A, B, C, and D as derived using ITS (Fig. 1). The variants of GLELO possessed sequence similarities of $88-96 \%$ at the DNA level and 90$100 \%$ at the protein level. Use of amino acid sequences to construct the tree led to branches $\mathrm{C}$ and $\mathrm{D}$ being grouped as a single clade (Fig. S2 in the Supplement), primarily due to the removal of codon degeneracies.

Recently, Wagner et al. (2013) studied the molecular phylogeny of the Mortierellales based on nuclear ribosomal
DNA. They reported that the $M$. alpina complex formed a heterogeneous cluster, as also found in this study. To compare both data sets, a NJ tree was constructed including 22 of the $M$. alpina sequences from Wagner et al. (2013). The tree (Fig. S3) possessed six clades, with all isolates of this study distributed in four of the six clades.

For the characterization of the ice nucleation activity of $M$. alpina, freezing tests were performed from 24 randomly selected representatives from among the clades. The total number of IN per gram of mycelium (fresh weight) was in the range of $\approx 10^{2}-10^{9}$ (Fig. 2 ). Generally, clade $C$ had distinctly lower numbers, namely $\approx 10^{2}-10^{6} \mathrm{~g}^{-1}$, while clade A and $\mathrm{B}$ had about $10^{8}-10^{9} \mathrm{~g}^{-1}$, and clade D $10^{6}-10^{9} \mathrm{~g}^{-1}$. When grouped according to different soil types (Fig. 3), the 23 


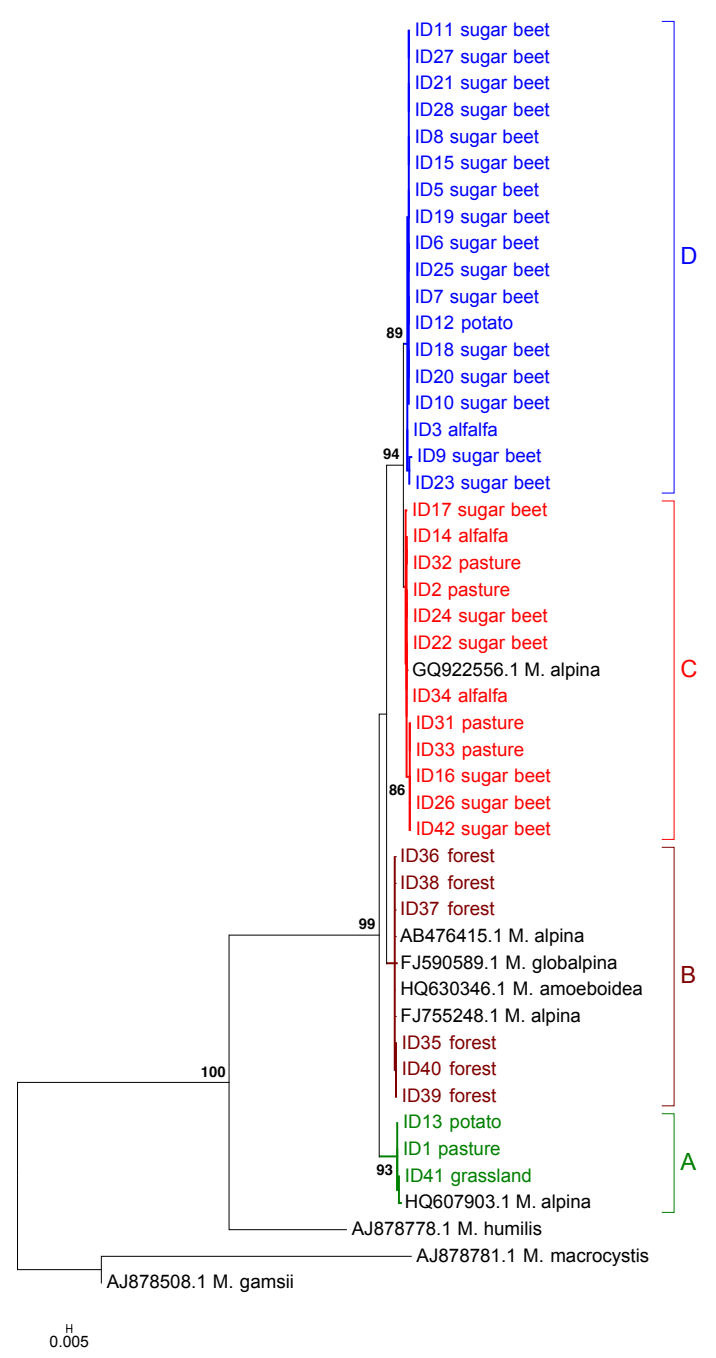

Figure 1. Neighbor-joining tree based on ITS sequences. The evolutionary distances were computed using the Tamura 3-parameter method (Tamura, 1992); units are the number of base substitutions per site. The rate variation among sites was modeled with a gamma distribution ( shape parameter $=0.25$ ). Node support above $75 \%$ is given. Note that the reference sequences named as M. globalpina and $M$. amoeboidea are also placed within the M. alpina complex as found by Wagner et al. (2013).

tested isolates from pasture, forest, sugar beet, grassland, and potato exhibited a consistency in possessing an intermediate range of between $\approx 10^{8}$ and $10^{9} \mathrm{IN}$ per gram of mycelium, whereas the single alfalfa field isolate had the lowest number of IN $\left(\approx 10^{5} \mathrm{~g}^{-1}\right), 3-4$ orders of magnitude less than the isolates from the other soil types.

To estimate the size and mass range of the IN, the mycelium/spore suspensions were filtered through $0.1 \mu \mathrm{m}$ pore diameter filters and Vivaspin ${ }^{\circledR}$ centrifugal concentrators with mass exclusion limits of 300 and $100 \mathrm{kDa}$. Filtrates of $0.1 \mu \mathrm{m}$ pore diameter filters as well as $300 \mathrm{kDa}$ spin columns retained activity (Table 4), but ice nucleation ac- tivity was removed after passage through a $100 \mathrm{kDa}$ device, with a few exceptions. This equates to a minimum diameter range of $6.1-8.8 \mathrm{~nm}$ for the cell-free IN of most isolates, while for some it suggests the IN are $<6.1 \mathrm{~nm}$ (Erickson, 2009). To further characterize the IN, aliquots of the $0.1 \mu \mathrm{m}$ filtrates were treated with different enzymes (papain, lipase), $6 \mathrm{M}$ guanidinium chloride, or $0.3 \mathrm{M}$ boric acid or were tested for heat stability at $60^{\circ} \mathrm{C}$ and $98^{\circ} \mathrm{C}$ (Fig. 4, Table 4). As shown in Table 4 the IN of most isolates were heat stable at $60^{\circ} \mathrm{C}$ but lost ice nucleation activity after $98^{\circ} \mathrm{C}$ treatment. Lipase and boric acid did not affect the ice nucleation activity significantly, whereas guanidinium chloride, a chemical that degrades proteins, had a strong effect. Treatment with the protein-degrading enzyme papain showed variable results: for clade A, papain had no effect, whereas clade B, $\mathrm{C}$, and $\mathrm{D}$ showed a strong decrease in their ice nucleation activity when digested with papain. Clade A was thus treated with another protease, pepsin, which also did not affect the ice nucleation activity.

\section{Discussion}

To our knowledge, this is the first report of ice nucleation activity in the widespread soil fungus M. alpina (Mortierellales). Note that the placement of the order Mortierellales is currently under discussion: it is either placed within the subphyla Mucoromycotina or Mortierellomycotina (Hibbett et al., 2007; Hoffmann et al., 2011). However, this is also the first reported case of ice nucleation activity in a zygomycotic fungi, as all reported INA fungi previously belonged to the phyla Ascomycota and Basidiomycota (Jayaweera and Flanagan, 1982; Kieft and Ahmadjian, 1989; Henderson-Begg et al., 2009; Iannone et al., 2011; Haga et al., 2013; Huffman et al., 2013; Morris et al., 2013).

Mortierella $(\approx 90$ species) are widespread and prominent members of soil and compost communities (Anastasi et al., 2005; Buée et al., 2009; Christensen, 2001; Nagy et al., 2011; Wagner et al., 2013), but they have also been found in air, sand storm dust, and rain samples (Hyland et al., 1953; Pawsey and Heath, 1964; Turner, 1966; Bokhary and Parvez, 1995; Kwaasi et al., 1998). Mortierella spp. are saprobic organisms utilizing decaying organic matter (Wagner et al., 2013), but, based on their ability to solubilize phosphorus, they can also form interactions with arbuscular mycorrhizal fungi, which are plant root symbionts (Zhang et al., 2011). They are also known to be hosts for mycoparasites (Turner, 1963; Upadhyay et al., 1981; Degawa and Gams, 2004) or are mycoparasites themselves (Willoughby, 1988).

The ability to act as an IN may be incidental in $M$. alpina, but its high temperature of activity suggests it provides an ecological advantage. The known INA fungi and bacteria (e.g., Pseudomonas syringae, Xanthomonas campestris, Fusarium avenaceum, Puccinia spp.) are mostly plant pathogens. Possession of ice nucleation activity has 


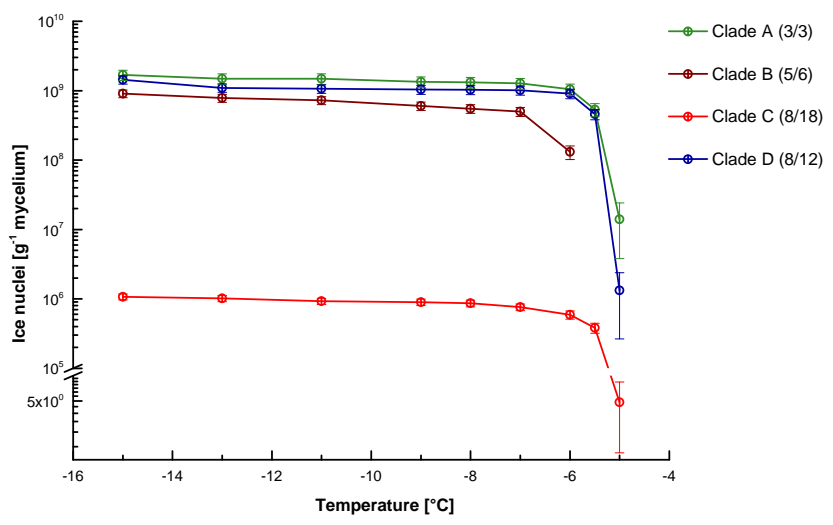

Figure 2. Average number of IN per gram of mycelium (fresh weight) for all clades. The clades are classified as (a) predominantly uncultivated, (b) forest, (c) predominantly standard agricultural, and (d) high organic matter input agricultural. The numbers in parentheses represent the number of isolates tested out of total number of isolates from each clade. Error bars represent the $95 \%$ confidence intervals.

been correlated with aggressiveness (Morris et al., 2010), and it is hypothesized that the ice nucleation activity may have preceded the acquisition of virulence factors by both promoting precipitation to aid dissemination (Morris et al., 2008,2010 ) and by helping to injure plant tissues to make nutrients available for establishment (Lindow, 1983; Morris et al., 2010).

M. alpina is not a pathogen, but it is a cold-adapted organism. The ice nucleation activity might be one aspect of its overwintering strategy, whereby physical damage can be avoided through protective extracellular freezing (Weete and Gandhi, 1999; Zachariassen and Kristiansen, 2000; Frisvad, 2008).

M. alpina is known to convert various carbon sources into lipids and to accumulate large amounts of fatty acids such as $\gamma$-linolenic, arachidonic, and eicosapentaenoic acid (Batrakov et al., 2002; Petkovits et al., 2011). The availability of much readily decomposable organic matter, due to the presence of many decaying fragments of sugar beet roots left behind after harvesting, may explain why $M$. alpina comprised $25 \%$ of all fungal isolates from sugar beet, the highest of any soil sampled in this study. Fatty acids are known to play a protective role in psychrotolerant Mortierella spp. (Weete and Gandhi, 1999; Frisvad, 2008). Arachidonic acid is a polyunsaturated fatty acid that can comprise up to $54 \%$ of the fatty acids in the mycelium (Weete and Gandhi, 1999; Lounds et al., 2007; Ho and Chen, 2008) and may help to regulate lipid fluidity, necessary for survival at low temperatures (Margesin and Schinner, 1994; Margesin et al., 2007). The ability of Mortierella to survive freezing was demonstrated by Morris et al. (1988), who obtained high recovery rates for M. elongata in cryo-preservation experiments using liquid nitrogen.

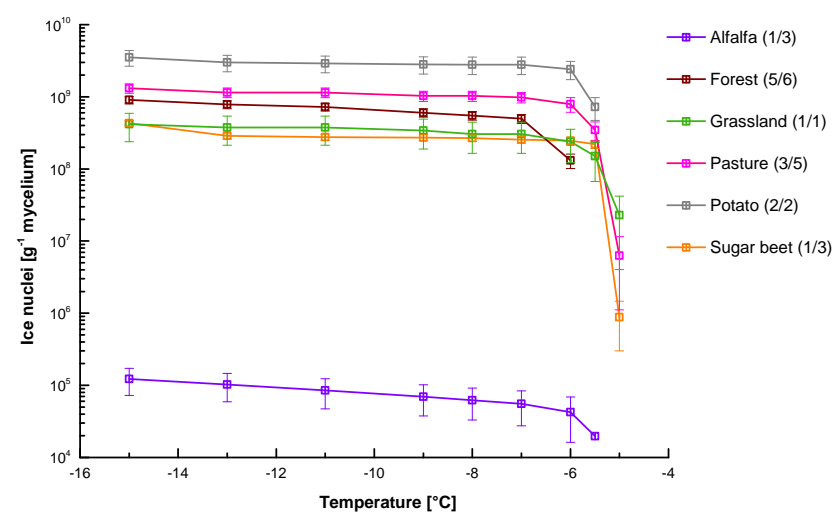

Figure 3. Average number of IN per gram of mycelium for the isolates of different soil types. The numbers in parentheses represent the number of isolates tested out of the total number of isolates each sampling site. Error bars represent the $95 \%$ confidence intervals.

Other than that, the ice nucleation activity may play a role in mycoparasitism or even be a useful mechanism for cleaving soil aggregates or rock to expose new surfaces to facilitate the release of phosphorus. As suggested for Fusarium and lichens (Kieft and Ahmadjian, 1989; Pouleur et al., 1992), the ice nucleation activity in M. alpina may also be beneficial in attracting moisture and water in relatively dry soils, e.g., for germination.

In terms of number of IN per gram of mycelium (up to $10^{9}$ ), the values obtained from M. alpina are similar to those obtained for $P$. syringae and Fusarium acuminatum (Pouleur et al., 1992). However, in contrast to bacterial IN, where different classes of IN are active at different temperatures due to different-sized aggregates (Phelps et al., 1986; Govindarajan and Lindow, 1988; Turner et al., 1990; Ruggles et al., 1993), the M. alpina IN seem to form only a single activity class within the tested temperature range. Interestingly, while the initial freezing temperature of -5 to $-6^{\circ} \mathrm{C}$ (Fig. 2, Table 3) would correspond to type 2 bacterial IN, i.e., the same as the glycoprotein structure (Kozloff et al., 1991; Ruggles et al., 1993), their $<300 \mathrm{kDa}$ size is only about one-tenth of the corresponding bacterial type 2 IN (Govindarajan and Lindow, 1988).

For further characterization of the IN, chemical, enzymatic, and thermal treatments were performed. The sensitivity to guanidinium chloride, papain, and $98^{\circ} \mathrm{C}$ heat treatment indicates that a protein is important in the activity of $M$. alpina IN. Interestingly, clade A IN are not affected by papain or pepsin, which might be explained by the specificity of the enzymes as clade A IN are also sensitive to guanidinium chloride, a chemical that degrades proteins. Thus, clade A IN seem to either differ in their amino acid sequence compared to the other clades, or might be protected by non-protein side chains. For all clades, lipids seem not to play any important role. Carbohydrate functionalization with boric acid showed no impact on the ice nucleation activity; however, the 
Table 4. Changes of number of IN in orders of magnitude after filtration $(5,0.1 \mu \mathrm{m} ; 300,100 \mathrm{kDa})$, thermal $\left(60,98^{\circ} \mathrm{C}\right)$, chemical $(\mathrm{guani}-$ dinium chloride $(\mathrm{G} . \mathrm{Cl})$ or boric acid (B.A)), or enzymatic (lipase, papain, pepsin) treatments at $-11^{\circ} \mathrm{C}$ relative to the activity of the $0.1 \mu \mathrm{m}$ filtrate of selected M. alpina isolates; dashes mean not measured.

\begin{tabular}{lrrrrrrrrrrr}
\hline Isolate & $5 \mu \mathrm{m}$ & $0.1 \mu \mathrm{m}$ & $300 \mathrm{kDa}$ & $100 \mathrm{kDa}$ & $60^{\circ} \mathrm{C}$ & $98{ }^{\circ} \mathrm{C}$ & $\mathrm{G} . \mathrm{Cl}$ & $\mathrm{B} . \mathrm{A}$ & Lip & Pap & Pep \\
\hline 01A & 0.4 & 0.0 & -0.4 & -5.8 & 0.2 & -4.2 & -4.8 & 0.0 & -0.2 & 0.0 & -0.7 \\
13A & 0.1 & 0.0 & 0.2 & -5.3 & 0.1 & -4.8 & -4.9 & 0.5 & -0.1 & 0.1 & -0.2 \\
41A & 0.3 & 0.0 & 0.1 & -6.0 & 0.2 & -4.6 & -4.1 & - & -0.4 & -1.0 & -0.1 \\
35B & -0.1 & 0.0 & -0.3 & -5.2 & -2.2 & -6.2 & -5.8 & - & - & - & - \\
36B & 0.2 & 0.0 & -0.2 & -5.4 & 0.0 & $<-7.0$ & -5.6 & -0.5 & -0.8 & -4.4 & - \\
37B & -0.3 & 0.0 & -0.2 & -3.2 & -0.5 & $<-7.0$ & $<-7.0$ & -0.7 & -0.7 & -2.6 & - \\
38B & 0.5 & 0.0 & 0.1 & -4.8 & -2.0 & -6.8 & $<-7.0$ & - & -0.8 & -4.4 & - \\
40B & 0.0 & 0.0 & 0.0 & -4.4 & -0.5 & $<-7.0$ & -6.2 & -0.2 & -0.3 & -2.2 & - \\
14C & 0.1 & 0.0 & 0.0 & $<-3.0$ & -0.4 & $<-3.0$ & $<-3.0$ & -0.2 & 0.0 & -2.6 & - \\
16C & 0.0 & 0.0 & 0.0 & -2.0 & 0.1 & -3.4 & $<-3.0$ & - & 0.0 & $<-3.0$ & - \\
17C & -0.3 & 0.0 & -0.1 & -4.2 & -1.2 & $<-4.0$ & $<-4.0$ & -0.6 & -0.5 & -3.6 & - \\
22C & 0.0 & 0.0 & 0.0 & $<-2.0$ & 0.1 & $<-2.0$ & $<-2.0$ & 0.0 & 0.0 & $<-2.0$ & - \\
26C & 0.2 & 0.0 & 0.0 & $<-0.5$ & $<-0.5$ & $<-0.5$ & $<-0.5$ & - & -0.2 & $<-0.5$ & - \\
31C & 0.8 & 0.0 & 0.2 & $<-3.0$ & -0.4 & $<-3.0$ & $<-3.0$ & - & - & - & - \\
33C & -0.2 & 0.0 & -0.6 & $<-3.0$ & -1.6 & $<-3.0$ & -3.1 & -0.2 & 0.0 & -2.5 & - \\
34C & - & 0.0 & -0.3 & $<-0.5$ & -0.3 & $<-0.5$ & $<-0.5$ & - & - & - & - \\
42C & 0.1 & 0.0 & -0.2 & $<-4.0$ & 0.0 & $<-4.0$ & $<-4.0$ & -0.9 & 0.1 & -2.8 & - \\
03D & -0.1 & 0.0 & 0.2 & -4.5 & 0.0 & -3.7 & -5.9 & 0.0 & -0.6 & -2.6 & - \\
05D & -0.3 & 0.0 & -0.5 & -5.1 & -0.5 & $<-7.0$ & -4.6 & - & - & - & - \\
06D & -0.3 & 0.0 & 0.0 & -5.7 & -0.2 & -5.7 & -5.3 & -0.2 & -0.3 & -3.3 & - \\
07D & 0.2 & 0.0 & 0.3 & -2.7 & -0.1 & -3.3 & -4.0 & 0.2 & 0.2 & -3.0 & - \\
09D & 0.1 & 0.0 & -0.7 & -6.8 & -0.4 & -5.4 & -3.4 & -0.9 & -0.6 & -3.4 & - \\
12D & -0.2 & 0.0 & -0.5 & -4.6 & -0.2 & -4.5 & -7.3 & -0.4 & -0.3 & -3.2 & - \\
15D & 0.2 & 0.0 & 0.0 & -4.6 & -0.1 & $<-5.0$ & -3.6 & 0.0 & -0.1 & -2.9 & - \\
19D & 0.2 & 0.0 & 0.0 & -4.9 & -0.1 & $<-5.0$ & $<-5.0$ & -0.1 & -0.3 & -3.0 & - \\
\hline
\end{tabular}

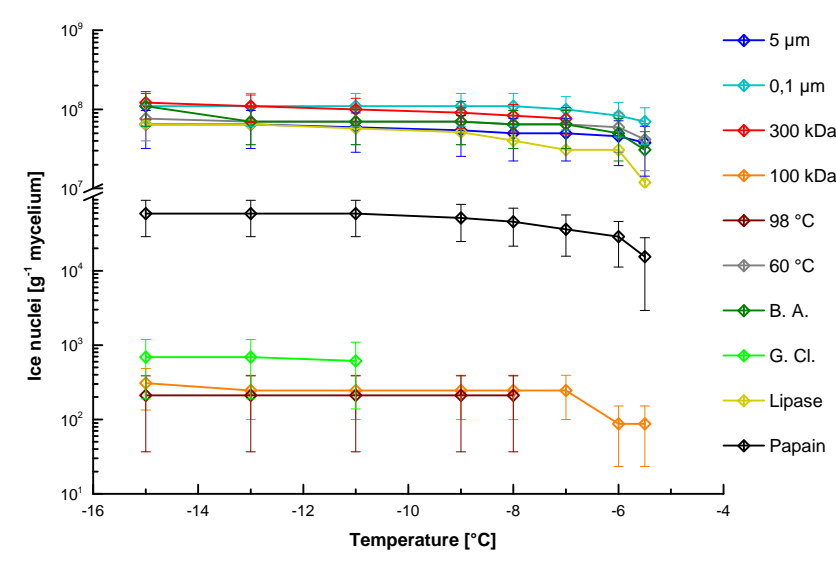

Figure 4. Number of IN per gram of mycelium for isolate ID6 after filtration, thermal, chemical, or enzymatic treatments. G. Cl stands for guanidinium chloride and B. A for boric acid. Error bars represent the $95 \%$ confidence intervals.

possible role of carbohydrates cannot be fully ruled out based on this method. Apart from rust fungi and pollen IN, which are thought to be non-proteinaceous (Pummer et al., 2012; Morris et al., 2013), evidence points to proteins as the source of ice nucleation activity of the known INA fungi (Fusarium, lichen mycobionts) (Kieft and Ruscetti, 1990; Hasegawa et al., 1994).

The IN of M. alpina have more similarities to Fusarium, lichen, and leaf-derived IN as they are not only cell-free but are also heat stable at $60^{\circ} \mathrm{C}$ (Schnell and Vali, 1976; Kieft and Ruscetti, 1990; Pouleur et al., 1992). The IN of M. alpina are smaller than $10 \mathrm{~nm}$ in size, between 100 and $300 \mathrm{kDa}$ in mass, and can be readily released into the surrounding medium. The latter is also a characteristic of several INA Fusarium species (Pouleur et al., 1992; Hasegawa et al., 1994; Tsumuki and Konno, 1994; Humphreys et al., 2001), leaf-derived IN (Schnell and Vali, 1973), some INA bacteria (Phelps et al., 1986; Kawahara et al., 1993), and INA pollen (Pummer et al., 2012). In soil and decaying vegetation, these cell-free IN might contribute to the as-yet-unknown reservoir of biological residues which can enhance the ice nucleation activity of soil dust and boundary layer atmospheric aerosols (Conen et al., 2011; Garcia et al., 2012; O'Sullivan et al., 2014; Tobo et al., 2014).

To understand the role of the IN of M. alpina and other INA fungi in soil and in the atmosphere, further surveys of INA fungi of all phyla, and in particular soil fungi, are clearly necessary. Additionally, studies investigating the occurrence and the distribution of the INA fungi in aerosol samples, 
samples of fugitive dust, and different agricultural and natural ecosystem soil types could help to estimate their contribution to the organic IN in soil and to establish relations to climatic zones. Recent studies have shown not only that the soilborne and airborne fungi are highly diverse (Buée et al., 2009; Fröhlich-Nowoisky et al., 2009; Schmidt et al., 2013) but also that their atmospheric transport leads to efficient exchange of species among ecosystems (Burrows et al., 2009a, b). The atmosphere serves as a primary medium for transport, and the global emissions of fungal spores are estimated to be $8-186 \mathrm{Tg} \mathrm{a}^{-1}$ (Després et al., 2012). Fungi have evolved several strategies for dispersal over long distances and at potentially high altitudes (Imshenetsky et al., 1978; Hawksworth, 2001; Brown and Hovmøller, 2002; Griffin, 2004; Prospero et al., 2005; Kellogg and Griffin, 2006; Elbert et al., 2007; Pearce et al., 2009; DeLeon-Rodriguez et al., 2013). Possession of ice nucleation activity that promotes the formation of precipitation would be a beneficial adaptation for airborne microbes since it aids their return to the land surface under favorable conditions (Sands et al., 1982; Morris et al., 2008). However, the release of small extracellular IN into the soil might unintentionally confer ice nucleation activity to a pool of small soil particles if the extracellular IN are embedded within or adsorbed. This population of fine dusts would occur at higher concentrations at cloud altitudes. Currently, this mechanism is not considered in models, which assume that fungal ice nucleation activity is restricted only to spores (Sesartic et al., 2013). Their potential contribution as IN in soil dusts depends critically upon whether or not they are rapidly decomposed by other soil microflora and whether they are de-activated or protected by adsorption onto soil organic matter and clays.

\section{Conclusions}

In this study we found ice nucleation activity in the widespread soil fungi $M$. alpina. Ice-nucleation-active isolates were obtained from six crop and native soils, with the highest abundance in soils with inputs of decomposable matter. The IN produced by $M$. alpina seem to be small extracellular proteins of $100-300 \mathrm{kDa}$ which are not anchored in the fungal cell wall. These small, cell-free IN might contribute to the as-yet-uncharacterized pool of atmospheric IN released from soils as dusts, so that the pool of biogenic IN might be larger than currently estimated. As the atmospheric importance of different INA fungi, either directly or indirectly via their extracellular IN, depends not only on their relative contribution to the IN in soil dusts but also on their number concentrations at cloud altitudes, further investigations are necessary for the identification of the IN themselves and the detection and quantification of these fungi and their IN in soil, precipitation, and atmospheric samples.

\section{The Supplement related to this article is available online at doi:10.5194/bg-12-1057-2015-supplement.}

Acknowledgements. Thanks for collaboration and support to M. O. Andreae, B. Baumgartner, J.-D. Förster, I. Germann-Müller, T. Godwill, L. E. Hanson, A. T. Kunert, M. Linden, J. Meeks, T. Pooya, S. Lelieveld, J. Odhiambo Obuya, C. Ruzene-Nespoli, and D. Sebazungu. The Max Planck Society (MPG), Ice Nuclei research UnIT (INUIT), the German Research Foundation (PO1013/5-1, FOR 1525 INUIT), and the National Science Foundation (NSF, grant 0841542 and 1358495) are acknowledged for financial support. This work is dedicated to Gary D. Franc for his pioneering work on atmospheric microbiology.

The service charges for this open-access publication have been covered by the Max Planck Society.

Edited by: H. Niemann

\section{References}

Agresti, A. and Coull, B. A.: Approximate is better than "exact" for interval estimation of binomial proportions, Am. Stat., 52, 119126, doi:10.2307/2685469, 1998.

Anastasi, A., Varese, G. C., and Marchisio, V. F.: Isolation and identification of fungal communities in compost and vermicompost, Mycologia, 97, 33-44, 2005.

Batrakov, S. G., Konova, I. V, Sheichenko, V. I., Esipov, S. E., Galanina, L. A., and Istratova, L. N.: Unusual fatty acid composition of cerebrosides from the filamentous soil fungus Mortierella alpina, Chem. Phys. Lipids, 117, 45-51, 2002.

Bokhary, H. A. and Parvez, S.: Fungi inhabiting household environments in Riyadh, Saudi Arabia, Mycopathologia, 130, 79-87, 1995.

Bowers, R. M., Lauber, C. L., Wiedinmyer, C., Hamady, M., Hallar, A. G., Fall, R., Knight, R., and Fierer, N.: Characterization of airborne microbial communities at a high-elevation site and their potential to act as atmospheric ice nuclei, Appl. Environ. Microbiol., 75, 5121-30, doi:10.1128/AEM.00447-09, 2009.

Brown, J. K. M. and Hovmøller, M. S.: Aerial dispersal of pathogens on the global and continental scales and its impact on plant disease, Science, 297, 537-41, doi:10.1126/science.1072678, 2002.

Buée, M., Reich, M., Murat, C., Morin, E., Nilsson, R. H., Uroz, S., and Martin, F.: 454 Pyrosequencing analyses of forest soils reveal an unexpectedly high fungal diversity, New Phytol., 184, 449-56, doi:10.1111/j.1469-8137.2009.03003.x, 2009.

Burrows, S. M., Butler, T., Jöckel, P., Tost, H., Kerkweg, A., Pöschl, U., and Lawrence, M. G.: Bacteria in the global atmosphere - Part 2: Modeling of emissions and transport between different ecosystems, Atmos. Chem. Phys., 9, 9281-9297, doi:10.5194/acp-9-9281-2009, 2009a.

Burrows, S. M., Elbert, W., Lawrence, M. G., and Pöschl, U.: Bacteria in the global atmosphere - Part 1: Review and synthesis of literature data for different ecosystems, Atmos. Chem. Phys., 9, 9263-9280, doi:10.5194/acp-9-9263-2009, 2009 b. 
Christensen, M.: Fungi associated with biological soil crusts in desert grasslands of Utah and Wyoming, Mycologia, 93, 432439, 2001.

Christner, B. C., Cai, R., Morris, C. E., McCarter, K. S., Foreman, C. M., Skidmore, M. L., Montross, S. N., and Sands, D. C.: Geographic, seasonal, and precipitation chemistry influence on the abundance and activity of biological ice nucleators in rain and snow, P. Natl. Acad. Sci. USA, 105, 18854-18859, doi:10.1073/pnas.0809816105, 2008.

Conen, F., Morris, C. E., Leifeld, J., Yakutin, M. V., and Alewell, C.: Biological residues define the ice nucleation properties of soil dust, Atmos. Chem. Phys., 11, 9643-9648, doi:10.5194/acp-119643-2011, 2011.

Creamean, J. M., Suski, K. J., Rosenfeld, D., Cazorla, A., DeMott, P. J., Sullivan, R. C., White, A. B., Ralph, F. M., Minnis, P., Comstock, J. M., Tomlinson, J. M., and Prather, K. A.: Dust and biological aerosols from the Sahara and Asia influence precipitation in the western U.S., Science, 339, 1572-1578, doi:10.1126/science.1227279, 2013.

Degawa, Y. and Gams, W.: A new species of Mortierella, and an associated sporangiiferous mycoparasite in a new genus Nothadelphia, Stud. Mycol., 50, 567-572, 2004.

DeLeon-Rodriguez, N., Lathem, T. L., Rodriguez-R, L. M., Barazesh, J. M., Anderson, B. E., Beyersdorf, A. J., Ziemba, L. D., Bergin, M., Nenes, A., and Konstantinidis, K. T.: Microbiome of the upper troposphere: species composition and prevalence, effects of tropical storms, and atmospheric implications, P. Natl. Acad. Sci. USA, 110, 2575-80, doi:10.1073/pnas.1212089110, 2013.

DeMott, P. J. and Prenni, A. J.: New Directions: Need for defining the numbers and sources of biological aerosols acting as ice nuclei, Atmos. Environ., 44, 1944-1945, doi:10.1016/j.atmosenv.2010.02.032, 2010.

Després, V. R., Huffman, A. J., Burrows, S. M., Hoose, C., Safatov, A. S., Buryak, G., Fröhlich-Nowoisky, J., Elbert, W., Andreae, M. O., Pöschl, U., and Jaenicke, R.: Primary biological aerosol particles in the atmosphere: a review, Tellus B, 64, 15598, doi:10.3402/tellusb.v64i0.15598, 2012.

Diehl, K., Quick, C., Matthias-Maser, S., Mitra, S. K., and Jaenicke, R.: The ice nucleating ability of pollen, Atmos. Res., 58, 75-87, doi:10.1016/S0169-8095(01)00091-6, 2001.

Elbert, W., Taylor, P. E., Andreae, M. O., and Pöschl, U.: Contribution of fungi to primary biogenic aerosols in the atmosphere: wet and dry discharged spores, carbohydrates, and inorganic ions, Atmos. Chem. Phys., 7, 4569-4588, doi:10.5194/acp-7-4569-2007, 2007.

Erickson, H. P.: Size and shape of protein molecules at the nanometer level determined by sedimentation, gel filtration, and electron microscopy., Biol. Proced. Online, 11, 32-51, doi:10.1007/s12575-009-9008-x, 2009.

Felsenstein, J.: Confidence limits on phylogenies: An approach using the bootstrap, Evolution (N. Y)., 39, 783-791, 1985.

Fierer, N., Strickland, M. S., Liptzin, D., Bradford, M. A., and Cleveland, C. C.: Global patterns in belowground communities, Ecol. Lett., 12, 1238-49, doi:10.1111/j.14610248.2009.01360.x, 2009.

Frisvad, J.: Fungi in cold ecosystems, in Psychrophiles: From Biodiversity to biotechnology, edited by G. C. Margesin Rosa,
Schinner Franz, Marx Jean-Claude, 137-156, Springer Berlin Heidelberg, 2008.

Fröhlich-Nowoisky, J., Pickersgill, D. A., Després, V. R., and Pöschl, U.: High diversity of fungi in air particulate matter, P. Natl. Acad. Sci. USA, 106, 12814-12819, 2009.

Garcia, E., Hill, T. C. J., Prenni, A. J., DeMott, P. J., Franc, G. D., and Kreidenweis, S. M.: Biogenic ice nuclei in boundary layer air over two U.S. High Plains agricultural regions, J. Geophys. Res. Atmos., 117, D18209, doi:10.1029/2012JD018343, 2012.

Georgakopoulos, D. G., Després, V., Fröhlich-Nowoisky, J., Psenner, R., Ariya, P. A., Pósfai, M., Ahern, H. E., Moffett, B. F., and Hill, T. C. J.: Microbiology and atmospheric processes: biological, physical and chemical characterization of aerosol particles, Biogeosciences, 6, 721-737, doi:10.5194/bg-6-721-2009, 2009.

Goldstein, G. and Nobel, P. S.: Changes in osmotic pressure and mucilage during low-temperature acclimation of Opuntia ficusindica, Plant Physiol., 97, 954-61, 1991.

Goldstein, G. and Nobel, P. S.: Water relations and low-temperature acclimation for cactus species varying in freezing tolerance, Plant Physiol., 104, 675-681, 1994.

Goudie, A. S. and Middleton, N. J.: Saharan dust storms: nature and consequences, Earth-Sci. Rev., 56, 179-204, doi:10.1016/S00128252(01)00067-8, 2001.

Govindarajan, A. G. and Lindow, S. E.: Size of bacterial icenucleation sites measured in situ by radiation inactivation analysis, P. Natl. Acad. Sci. USA, 85, 1334-8, 1988.

Griffin, D. W.: Terrestrial microorganisms at an altitude of $20000 \mathrm{~m}$ in Earth's atmosphere, Aerobiologia, 20, 135-140, doi:10.1023/B:AERO.0000032948.84077.12, 2004.

Haga, D. I., Iannone, R., Wheeler, M. J., Mason, R., Polishchuk, E. A., Fetch, T., van der Kamp, B. J., McKendry, I. G., and Bertram, A. K.: Ice nucleation properties of rust and bunt fungal spores and their transport to high altitudes, where they can cause heterogeneous freezing, J. Geophys. Res. Atmos., 118, 7260-7272, doi:10.1002/jgrd.50556, 2013.

Hasegawa, Y., Ishihara, Y., and Tokuyama, T.: Characteristics of ice-nucleation activity in Fusarium avenaceum IFO 7158, Biosci. Biotechnol. Biochem., 58, 2273-2274, doi:10.1271/bbb.58.2273, 1994 .

Hawksworth, D.: The magnitude of fungal diversity: the 1.5 million species estimate revisited, Mycol. Res., 105, 1422-1432, 2001.

Henderson-Begg, S. K., Hill, T., Thyrhaug, R., Khan, M., and Moffett, B. F.: Terrestrial and airborne non-bacterial ice nuclei, Atmos. Sci. Lett., 10, 215-219, doi:10.1002/as1.241, 2009.

Hibbett, D. S., Binder, M., Bischoff, J. F., Blackwell, M., Cannon, P. F., Eriksson, O. E., Huhndorf, S., James, T., Kirk, P. M., Lücking, R., Thorsten Lumbsch, H., Lutzoni, F., Matheny, P. B., McLaughlin, D. J., Powell, M. J., Redhead, S., Schoch, C. L., Spatafora, J. W., Stalpers, J. A., Vilgalys, R., Aime, M. C., Aptroot, A., Bauer, R., Begerow, D., Benny, G. L., Castlebury, L. A., Crous, P. W., Dai, Y.-C., Gams, W., Geiser, D. M., Griffith, G. W., Gueidan, C., Hawksworth, D. L., Hestmark, G., Hosaka, K., Humber, R. A., Hyde, K. D., Ironside, J. E., Kõljalg, U., Kurtzman, C. P., Larsson, K.-H., Lichtwardt, R., Longcore, J., Miadlikowska, J., Miller, A., Moncalvo, J.-M., Mozley-Standridge, S., Oberwinkler, F., Parmasto, E., Reeb, V., Rogers, J. D., Roux, C., Ryvarden, L., Sampaio, J. P., Schüssler, A., Sugiyama, J., Thorn, R. G., Tibell, L., Untereiner, W. A., Walker, C., Wang, Z., Weir, A., Weiss, M., White, M. M., Winka, K., Yao, Y.-J., and Zhang, 
N.: A higher-level phylogenetic classification of the Fungi, Mycol. Res., 111, 509-47, doi:10.1016/j.mycres.2007.03.004, 2007.

Hill, T. C. J., Moffett, B. F., Demott, P. J., Georgakopoulos, D. G., Stump, W. L., and Franc, G. D.: Measurement of ice nucleation-active bacteria on plants and in precipitation by quantitative PCR, Appl. Environ. Microbiol., 80, 1256-67, doi:10.1128/AEM.02967-13, 2014.

Ho, S. Y. and Chen, F.: Genetic characterization of Mortierella alpina by sequencing the $18 \mathrm{~S}-28 \mathrm{~S}$ ribosomal gene internal transcribed spacer region, Lett. Appl. Microbiol., 47, 250-255, doi:10.1111/j.1472-765X.2008.02427.x, 2008.

Hoffmann, K., Voigt, K., and Kirk, P. M.: Mortierellomycotina subphyl. nov., based on multi-gene genealogies, Mycotaxon, 115, 353-363, doi:10.5248/115.353, 2011.

Huffman, J. A., Prenni, A. J., DeMott, P. J., Pöhlker, C., Mason, R. H., Robinson, N. H., Fröhlich-Nowoisky, J., Tobo, Y., Després, V. R., Garcia, E., Gochis, D. J., Harris, E., Müller-Germann, I., Ruzene, C., Schmer, B., Sinha, B., Day, D. A., Andreae, M. O., Jimenez, J. L., Gallagher, M., Kreidenweis, S. M., Bertram, A. K., and Pöschl, U.: High concentrations of biological aerosol particles and ice nuclei during and after rain, Atmos. Chem. Phys., 13, 6151-6164, doi:10.5194/acp-13-6151-2013, 2013.

Humphreys, T. L., Castrillo, L. A., and Lee, M. R.: Sensitivity of partially purified ice nucleation activity of Fusarium acuminatum SRSF 616, Curr. Microbiol., 42, 330-338, doi:10.1007/s002840010225, 2001.

Hyland, F., Graham, B. F., Steinmetz, F. H., and Vickers, M. A.: Maine air-borne pollen and fungous spore survey, Univ. Maine, Orono, 1953.

Iannone, R., Chernoff, D. I., Pringle, A., Martin, S. T., and Bertram, A. K.: The ice nucleation ability of one of the most abundant types of fungal spores found in the atmosphere, Atmos. Chem. Phys., 11, 1191-1201, doi:10.5194/acp-11-1191-2011, 2011.

Imshenetsky, A. A., Lysenko, S. V., and Kazakov, G. A.: Upper boundary of the biosphere., Appl. Environ. Microbiol., 35, 1-5, 1978.

Jayaweera, K. and Flanagan, P.: Investigations on biogenic ice nuclei in the arctic atmosphere, Geophys. Res. Lett., 9, 94-97, 1982.

Joergensen, R. and Wichern, F.: Quantitative assessment of the fungal contribution to microbial tissue in soil, Soil Biol. Biochem., 40, 2977-2991, doi:10.1016/j.soilbio.2008.08.017, 2008.

Kawahara, H., Yoshinori, M., and Obata, H.: Purification and characterization of extracellular ice-nucleating matter from Erwinia uredovora VKUIN-3, Biosci. Biotech. Biochem., 57, 14291432, 1993.

Kellogg, C. and Griffin, D.: Aerobiology and the global transport of desert dust, Trends Ecol. Evol., 21, 638-44, doi:10.1016/j.tree.2006.07.004, 2006.

Kieft, T. and Ahmadjian, V.: Biological ice nucleation activity in lichen mycobionts and photobionts, Lichenologist, 21, 355-362, 1989.

Kieft, T. L.: Ice nucleation activity in lichens, Appl. Environ. Microbiol., 54, 1678-81, 1988.

Kieft, T. L. and Ruscetti, T.: Characterization of biological ice nuclei from a lichen, J. Bacteriol., 172, 3519-23, 1990.

Kozloff, L. M., Turner, M. A., and Arellano, F.: Formation of bacterial membrane ice-nucleating lipoglycoprotein complexes, J. Bacteriol., 173, 6528-36, 1991.
Krog, J. O., Zachariassen, K. E., Larsen, B., and Smidsrød, O.: Thermal buffering in Afro-alpine plants due to nucleating agent-induced water freezing, Nature, 282, 300-301, doi:10.1038/282300a0, 1979.

Kwaasi, A. A. A., Parhar, R. S., Al-Mohanna, F. A. A., Harfi, H. A., Collison, K. S., and Al-Sedairy, S. T.: Aeroallergens and viable microbes in sandstorm dust, Allergy, 53, 255-265, doi:10.1111/j.1398-9995.1998.tb03885.x, 1998.

Kwaśna, H., Ward, E., and Bateman, G. L.: Phylogenetic relationships among Zygomycetes from soil based on ITS1/2 rDNA sequences, Mycol. Res., 110, 501-10, doi:10.1016/j.mycres.2006.02.004, 2006.

Lindow, S.: The role of bacterial ice nucleation in frost injury to plants, Annu. Rev. Phytopathol., 21, 363-384, 1983.

Lounds, C., Eagles, J., Carter, A. T., MacKenzie, D. A., and Archer, D. B.: Spore germination in Mortierella alpina is associated with a transient depletion of arachidonic acid and induction of fatty acid desaturase gene expression, Arch. Microbiol., 188, 299305, doi:10.1007/s00203-007-0248-3, 2007.

Margesin, R. and Schinner, F.: Properties of cold-adapted microorganisms and their potential role in biotechnology, J. Biotechnol. 33, 1-14, doi:10.1016/0168-1656(94)90093-0, 1994.

Margesin, R., Neuner, G., and Storey, K. B.: Cold-loving microbes, plants, and animals-fundamental and applied aspects, Naturwissenschaften, 94, 77-99, doi:10.1007/s00114-006-0162-6, 2007.

Morris, C. E., Georgakopoulos, D. G., and Sands, D. C.: Ice nucleation active bacteria and their potential role in precipitation, J. Phys. IV, 121, 87-103, doi:10.1051/jp4:2004121004, 2004.

Morris, C. E., Sands, D. C., Vinatzer, B. A., Glaux, C., Guilbaud, C., Buffière, A., Yan, S., Dominguez, H., and Thompson, B. M.: The life history of the plant pathogen Pseudomonas syringae is linked to the water cycle., ISME J., 2, 321-34, doi:10.1038/ismej.2007.113, 2008.

Morris, C. E., Sands, D. C., Vanneste, J. L., Montarry, J., Oakley, B., Guilbaud, C., and Glaux, C.: Inferring the evolutionary history of the plant pathogen Pseudomonas syringae from its biogeography in headwaters of rivers in North America, Europe, and New Zealand., MBio, 1, 1-11, doi:10.1128/mBio.00107-10, 2010.

Morris, C. E., Sands, D. C., Glaux, C., Samsatly, J., Asaad, S., Moukahel, A. R., Gonçalves, F. L. T., and Bigg, E. K.: Urediospores of rust fungi are ice nucleation active at $>-10^{\circ} \mathrm{C}$ and harbor ice nucleation active bacteria, Atmos. Chem. Phys., 13, 4223-4233, doi:10.5194/acp-13-4223-2013, 2013.

Morris, G. J., Smith, D., and Coulson, G. E.: A comparative study of the changes in the morphology of hyphae during freezing and viability upon thawing for twenty species of fungi, Microbiology, 134, 2897-2906, doi:10.1099/00221287-134-11-2897, 1988.

Nagy, L. G., Petkovits, T., Kovács, G. M., Voigt, K., Vágvölgyi, C., and Papp, T.: Where is the unseen fungal diversity hidden? A study of Mortierella reveals a large contribution of reference collections to the identification of fungal environmental sequences, New Phytol., 191, 789-94, doi:10.1111/j.14698137.2011.03707.x, 2011.

Nilsson, R. and Kristiansson, E.: Intraspecific ITS variability in the kingdom Fungi as expressed in the international sequence databases and its implications for molecular species identification, Evol. Bioinform. Online, 4, 193-201, 2008.

O'Sullivan, D., Murray, B. J., Malkin, T. L., Whale, T. F., Umo, N. S., Atkinson, J. D., Price, H. C., Baustian, K. J., Browse, J., 
and Webb, M. E.: Ice nucleation by fertile soil dusts: relative importance of mineral and biogenic components, Atmos. Chem. Phys., 14, 1853-1867, doi:10.5194/acp-14-1853-2014, 2014.

Pawsey, R. G. and Heath, L. A. F.: An investigation of the spore population of the air at Nottingham, Trans. Br. Mycol. Soc., 47, 351-355, doi:10.1016/S0007-1536(64)80007-3, 1964.

Pearce, D. A., Bridge, P. D., Hughes, K. A., Sattler, B., Psenner, R., and Russell, N. J.: Microorganisms in the atmosphere over Antarctica, FEMS Microbiol. Ecol., 69, 143-57, doi:10.1111/j.1574-6941.2009.00706.x, 2009.

Petkovits, T., Nagy, L. G., Hoffmann, K., Wagner, L., Nyilasi, I., Griebel, T., Schnabelrauch, D., Vogel, H., Voigt, K., Vágvölgyi, C., and Papp, T.: Data partitions, Bayesian analysis and phylogeny of the zygomycetous fungal family Mortierellaceae, inferred from nuclear ribosomal DNA sequences, PLoS One, 6, e27507, doi:10.1371/journal.pone.0027507, 2011.

Phelps, P., Giddings, T. H., Prochoda, M., and Fall, R.: Release of cell-free ice nuclei by Erwinia herbicola, J. Bacteriol., 167, 496502, 1986.

Pouleur, S., Richard, C., Martin, J. G., and Antoun, H.: Ice nucleation activity in Fusarium acuminatum and Fusarium avenaceum, Appl. Environ. Microbiol., 58, 2960-4, 1992.

Pratt, K. A., DeMott, P. J., French, J. R., Wang, Z., Westphal, D. L., Heymsfield, A. J., Twohy, C. H., Prenni, A. J., and Prather, K. A.: In situ detection of biological particles in cloud ice-crystals, Nat. Geosci., 2, 398-401, doi:10.1038/ngeo521, 2009.

Prospero, J. M., Blades, E., Mathison, G., and Naidu, R.: Interhemispheric transport of viable fungi and bacteria from Africa to the Caribbean with soil dust, Aerobiologia, 21, 1-19, doi:10.1007/s10453-004-5872-7, 2005.

Pummer, B. G., Bauer, H., Bernardi, J., Bleicher, S., and Grothe, H.: Suspendable macromolecules are responsible for ice nucleation activity of birch and conifer pollen, Atmos. Chem. Phys., 12, 2541-2550, doi:10.5194/acp-12-2541-2012, 2012.

Richard, C., Martin, J., and Pouleur, S.: Ice nucleation activity identified in some phytopathogenic Fusarium species, Phytoprotection, 77, 83, doi:10.7202/706104ar, 1996.

Ruggles, J. A., Nemecek-Marshall, M., and Fall, R.: Kinetics of appearance and disappearance of classes of bacterial ice nuclei support an aggregation model for ice nucleus assembly, J. Bacteriol., 175, 7216-21, 1993.

Sands, D., Langhans, V., Scharen, A., and De Smet, G.: The association between bacteria and rain and possible resultant meteorological implications, Idojaras, 86(, 148-151, 1982.

Schmidt, P.-A., Bálint, M., Greshake, B., Bandow, C., Römbke, J., and Schmitt, I.: Illumina metabarcoding of a soil fungal community, Soil Biol. Biochem., 65, 128-132, doi:10.1016/j.soilbio.2013.05.014, 2013.

Schnell, R. C. and Vali, G.: Atmospheric ice nuclei from decomposing vegetation, Nature, 236, 163-165, doi:10.1038/236163a0, 1972.

Schnell, R. C. and Vali, G.: World-wide source of leaf derived freezing nuclei, Nature, 246, 212-213, doi:10.1038/246212a0, 1973.

Schnell, R. C. and Vali, G.: Biogenic Ice Nuclei: Part I. Terrestrial and Marine Sources, J. Atmos. Sci., 33, 1554-1564, doi:10.1175/1520-0469(1976)033<1554:BINPIT>2.0.CO;2, 1976.
Sesartic, A., Lohmann, U., and Storelvmo, T.: Modelling the impact of fungal spore ice nuclei on clouds and precipitation, Environ. Res. Lett., 8, 014029, doi:10.1088/1748-9326/8/1/014029, 2013.

Sing, D. and Sing, C. F.: Impact of direct soil exposures from airborne dust and geophagy on human health, Int. J. Environ. Res. Public Health, 7, 1205-23, doi:10.3390/ijerph7031205, 2010.

Takeno, S., Sakuradani, E., Murata, S., Inohara-Ochiai, M., Kawashima, H., Ashikari, T., and Shimizu, S.: Molecular evidence that the rate-limiting step for the biosynthesis of arachidonic acid in Mortierella alpina is at the level of an elongase, Lipids, 40, 25-30, 2005.

Tamura, K.: Estimation of the number of nucleotide substitutions when there are strong transition-transversion and $\mathrm{G}+\mathrm{C}$-content biases, Mol. Biol. Evol., 9, 678-687, 1992.

Tamura, K., Peterson, D., Peterson, N., Stecher, G., Nei, M., and Kumar, S.: MEGA5: molecular evolutionary genetics analysis using maximum likelihood, evolutionary distance, and maximum parsimony methods, Mol. Biol. Evol., 28, 2731-2739, doi:10.1093/molbev/msr121, 2011.

Tobo, Y., DeMott, P. J., Hill, T. C. J., Prenni, A. J., SwobodaColberg, N. G., Franc, G. D., and Kreidenweis, S. M.: Organic matter matters for ice nuclei of agricultural soil origin, Atmos. Chem. Phys., 14, 8521-8531, doi:10.5194/acp-14-8521-2014, 2014.

Tsumuki, H. and Konno, H.: Ice nuclei produced by Fusarium $s p$. isolated from the gut of the rice stem borer, Chilo suppressalis WALKER (Lepidoptera: Pyralidae), Biosci. Biotechnol. Biochem., 58, 578-579, doi:10.1271/bbb.58.578, 1994.

Turner, M.: Studies in the genus Mortierella, Trans. Br. Mycol. Soc., 46, 262-IN6, doi:10.1016/S0007-1536(63)80082-0, 1963.

Turner, M. A., Arellano, F., and Kozloff, L. M.: Three separate classes of bacterial ice nucleation structures, J. Bacteriol., 172, 2521-6, 1990 .

Turner, P. D.: The fungal air spora of Hong Kong as determined by the agar plate method, Trans. Br. Mycol. Soc., 49, 255-267, doi:10.1016/S0007-1536(66)80060-8, 1966.

Upadhyay, R. S., Rai, B., and Gupta, R. C.: Fusarium udum as a mycoparasite of Mortierella subtilissima, Plant Soil, 60, 149-151, doi:10.1007/BF02377121, 1981.

Vali, G., Christensen, M., Fresh, R. W., Galyan, E. L., Maki, L. R. and Schnell, R. C.: Biogenic ice nuclei. Part II: Bacterial sources, J. Atmos. Sci., 33, 1565-1570, doi:10.1175/15200469(1976)033<1565:BINPIB>2.0.CO;2, 1976.

Wagner, L., Stielow, B., Hoffmann, K., Petkovits, T., Papp, T., Vágvölgyi, C., de Hoog, G. S., Verkley, G., and Voigt, K.: A comprehensive molecular phylogeny of the Mortierellales (Mortierellomycotina) based on nuclear ribosomal DNA, Persoonia, Mol. Phylogeny Evol. Fungi, 30, 77-93, doi:10.3767/003158513X666268, 2013.

Wardle, D. A.: A comparative assesment of factors which influence microbial biomass carbon and nitrogen levels in soil, Biol. Rev., 67, 321-358, doi:10.1111/j.1469-185X.1992.tb00728.x, 1992.

Warren, G. J.: Identification and analysis of ina genes and proteins, in Biological ice nucleation and its applications, edited by: Lee, L. V. G. R. E. and Warren, G. J.,85-99, American Phyotpathological Society Press, St. Paul, MN., 1995.

Weete, J. and Gandhi, S.: Sterols and fatty acids of the Mortierellaceae: taxonomic implications, Mycologia, 91, 642-649, 1999. 
White, T., Bruns, T., Lee, S., and Taylor, J.: Amplification and direct sequencing of fungal ribosomal RNA genes for phylogenetics, in: PCR Protocols: a guide to methods and applications, edited by: Innis, M. A., Gelfand, D. H., Sninsky, J. J., and White, T. J., Academic Press, New York, USA, 315-322, 1990.

Willoughby, L. G.: Saprolegnia parasitized by Mortierella alpina, Trans. Br. Mycol. Soc., 90, 496-499, doi:10.1016/S00071536(88)80165-7, 1988.

Zachariassen, K. E. and Kristiansen, E.: Ice nucleation and antinucleation in nature, Cryobiology, 41, 257-79, doi:10.1006/cryo.2000.2289, 2000.
Zak, D. R., Tilman, D., Parmenter, R. R., Rice, C. W., Fisher, F. M., Vose, J., Milchunas, D., and Martin, C. W.: Plant production and soil microorganisms in late-successional ecosystems: A continental-scale study, Ecology, 75, 2333, doi:10.2307/1940888, 1994.

Zhang, H., Wu, X., Li, G., and Qin, P.: Interactions between arbuscular mycorrhizal fungi and phosphate-solubilizing fungus (Mortierella sp.) and their effects on Kostelelzkya virginica growth and enzyme activities of rhizosphere and bulk soils at different salinities, Biol. Fertil. Soils, 47, 543-554, doi:10.1007/s00374-011-0563-3, 2011. 